\title{
CROSS-REACTIVITY OF ANTIBODIES IN HUMAN INFECTIONS BY THE KINETOPLASTID PROTOZOA TRYPANOSOMA CRUZI, LEISHMANIA CHAGASI AND LEISHMANIA (VIANNIA) BRAZILIENSIS
}

\author{
Ana de Cássia VEXENAT, Jaime M. SANTANA \& Antonio R.L. TEIXEIRA
}

\begin{abstract}
SUMMARY
We have detected antibodies, in the sera of Chagas disease, Kala-azar and Mucocutaneous leishmaniasis patients, that bind multiple antigens shared between the three causative agents. The Chagas disease sera showed 98 to 100\% positive results by ELISA when the Leishmania braziliensis and Leishmania chagasi antigens were used, respectively. The Kala-azar sera showed $100 \%$ positive results with Trypanosoma cruzi or L. braziliensis antigens by immunofluorescence assays. The antibodies in the sera of Mucocutaneous leishmaniasis patients showed $100 \%$ positive results by ELISA assays with $T$. cruzi or $L$. chagasi antigens. Furthermore, the direct agglutination of $L$. chagasi promastigotes showed that $95 \%$ of Kala-azar and $35 \%$ of Mucocutaneous leishmaniasis sera agglutinated the parasite in dilutions above 1:512. In contrast, $15 \%$ of Chagas sera agglutinated the parasite in dilutions 1:16 and below.

Western blot analysis showed that the Chagas sera that formed at least 24 bands with the $T$. cruzi also formed 13 bands with the L. chagasi and 17 bands with the L. braziliensis. The Kala-azar sera that recognized at least 29 bands with the homologous antigen also formed 14 bands with the T. cruzi and 10 bands with the L. braziliensis antigens. Finally, the Mucocutaneous leishmaniasis sera that formed at least 17 bands with the homologous antigen also formed 10 bands with the T. cruzi and four bands with the L. chagasi antigens. These results indicate the presence of common antigenic determinants in several protozoal proteins and, therefore, explain the serologic cross-reactions reported here.
\end{abstract}

KEYWORDS: Kinetoplastid protozoa; Trypanosoma cruzi; Leishmania chagasi; Leishmania (Viannia) braziliensis; Cross-reactive antibodies; Human infections.

\section{INTRODUCTION}

The flagellate protozoa $T$. cruzi, L. chagasi and $L$. braziliensis are the arthropod-transmitted agents of Chagas disease, Kala-azar and Mucocutaneous leishmaniasis, respectively. These flagellates are sympatric in a number of geographic regions of South America ${ }^{1,14}$. Although these infectious agents show some common biologic features, they produce distinct pathologies with broad clinical and epidemiologic significance. It has been estimated that 18 million people are infected with $T$. cruzi ${ }^{22}$, and two million with the Leishmaniasis ${ }^{7}$. These endemic diseases are major public health problems, causing physical disability and severe economic burden in the rural populations of South America.

Diagnosis of each of these protozoal infections is made by direct microscopic examination of blood samples, bone marrow aspirates or biopsies of ulcerated skin lesions. Either the blood or the macerates of solid tissues can be cultured in liquid medium or injected into susceptible laboratory animals for final demonstration of

\footnotetext{
Grant support: FINEP, Financiadora de Estudos e Projetos.

Laboratório Multidisciplinar de Pesquisa em Deonça de Chagas. Faculdade de Ciências da Saúde da Universidade de Brasilia. Caixa Postal 04685, 70919-970

Correspondence to: Dr. Antonio R.L. Teixeira, Laboratório Multidisciplinar de Pesquisa em Doença de Chagas, Faculdade de Ciências da Saúde, Universidade de Brasilia. Caixa Postal 04685, 70919-970 Brasilia, DF, Brasil, FAX: (061) 273-4645.
} 
VEXENAT, A. de C.; SANTANA, J.M. \& TEIXEIRA, A.R.L. - Cross-reactivity of antibodies in human infections by the kinetoplastid protozoa Trypanosoma cruzi, Leishmania chagasi and Leishmania (Viannia) braziliensis. Rev. Inst. Med. trop. S. Paulo, 38(3):177-185, 1996.

the parasite ${ }^{5}$. All these time-consuming procedures are usually effective in the overt acute phase of the infections. However, in the chronic infections several immunological assays have been used for performing diagnoses. Physicians and field-workers frequently rely on indirect immunofluorescence (IF), indirect hemagglutination $(\mathrm{IH})$, enzyme-linked immunosorbent assay (ELISA) and passive agglutination of the parasite culture forms by serum antibodies, in order to obtain information on the possible causal agent of the infections. Also, skin reactions against antigens from these Trypanosomatidae have been employed ${ }^{12,19}$.

The close relationship shown by these protozoa of the order Kinetoplastida suggests that common antigens may be encountered among these species. In fact, early studies have shown some degree of serologic cross-reactivity among these distinctive clinical entities $3,4,11,13$. In this paper we examine the common antigenic determinants in whole cell protein from these flagellates, and on the extent of cross-reactivity among antisera obtained from Chagas disease, Kala-azar and Mucocutaneous leishmaniasis patients.

\section{MATERIALS AND METHODS}

\section{Parasites:}

Trypanosoma cruzi: The T12E clone derived from the Ernestina stock of the parasite was used in this study. This stock was isolated from a child with acute Chagas disease ${ }^{15}$ and has been maintained in the laboratory through serial passages in liver infusion tryptose (LIT) and, also, in blood-agar bi-phasic medium. The parasite cloning was performed in fetal mouse skeletal muscle culture infected with a single blood trypomastigote ${ }^{18}$. The protein preparation obtained from epimastigote forms grown in LIT medium supplemented with $5 \%$ fetal calf serum (FCS) was used.

Leishmania chagasi: The EO1345 stock of the parasite isolated from the vector Lutzomyia longipalpis at the State of Bahia, Brazil, was employed. The zymodeme and schizodeme profiles of this parasite have been characterized $^{16}$. The promastigote forms grown in LIT medium with $20 \%$ FCS supplemented with gentamycin $(50 \mu \mathrm{g} / \mathrm{ml})$ and penicillin $(100 \mathrm{IU} / \mathrm{ml})$, were used in this study.

Leishmania (Viannia) braziliensis: The LTB300 stock of the parasite ${ }^{6}$ was used. The cells were grown in Schneider's Drosophila medium (Gibco, USA) with $20 \%$ FCS supplemented with $1 \mathrm{mM}$ L-thyrosine, $5 \mathrm{mM}$ L-cysteine and $7.5 \%$ sodium bicarbonate, $\mathrm{pH} 7.2$.

\section{Antigens}

Whole cell protein: The exponential growth phase $T$. cruzi, L. braziliensis and L. chagasi were used for obtaining soluble antigens. Usually $1 \times 10^{8}$ culture forms were collected and washed three times in PBS, pH 7.2. The pellet was resuspended in 1:10 (w/v) double distilled water and frozen at $-20^{\circ} \mathrm{C}$. After three cycles of freezing and thawing, the ruptured cells were sedimented by centrifugation at $5000 \mathrm{x} \mathrm{g}$ for $20 \mathrm{~min}$. The supernatant retained the soluble proteins, which were mixed with the proteinase inhibitors ( $1 \mathrm{mM}$ PMSF, $1 \mathrm{mM}$ EDTA and $10 \mu \mathrm{M}$ TLCK) and used in these experiments. The protein content in the soluble antigen was determined by LOWRY's ${ }^{10}$ method.

Killed parasites: The $T$. cruzi and L. braziliensis forms grown in liquid media were used for preparation of antigens. Usually the exponential growth phase parasites were harvested from $100 \mathrm{ml}$ of culture medium. After centrifugation at $1500 \mathrm{x} \mathrm{g}$ for $10 \mathrm{~min}$, the sedimented parasites were washed three times in PBS, pH 7.2. The cells were then suspended in PBS and fixed in $2 \%$ formaldehyde $(\mathrm{v} / \mathrm{v})$ final concentration, overnight at $4^{\circ} \mathrm{C}$. After centrifugation and washings in PBS the dead parasites were diluted to $6 \times 10^{3}$ cells $/ \mathrm{ml}$ in distilled water. $5 \mu \mathrm{l}$ of the cell suspension were dipped onto each division on the surface of glass slides, air dried, wrapped on aluminum foil and frozen at $-20^{\circ} \mathrm{C}$ until use.

The L. chagasi $\left(10^{7}\right.$ cells $\left./ \mathrm{ml}\right)$ cells were collected by centrifugation and washed three times in Locke's solution, at $1500 \mathrm{xg}$ for $15 \mathrm{~min}$. These parasites were resuspended in Locke's containing $0.4 \%(\mathrm{v} / \mathrm{w})$ trypsin (Difco). After incubation at $37^{\circ} \mathrm{C}$, for $45 \mathrm{~min}$, the cells were washed three times. The parasite cells were resuspended overnight in the same solution containing $2 \%$ formaldehyde. After two washings in citrate-saline $(0.15 \mathrm{M} \mathrm{NaCl}, 0.05 \mathrm{M}$ sodium citrate) the cells were resuspended in Locke's solution containing $1 \%$ Coomassie brilliant blue. The dead parasites were kept under agitation for $90 \mathrm{~min}$, washed twice with citrate-saline and resuspended in the same solution containing $0.43 \%$ formaldehyde. This antigen was stored in dark bottle, at $4^{\circ} \mathrm{C}$, until use.

\section{Serum samples:}

Chagas disease: The 64 samples of Chagas patient sera used in this study were from street-sweepers at the Cleaning Department of Brasília, Brazil. All these chronically infected patients were born in poor rural areas of the States of Goiás, Minas Gerais and Bahia, where $T$. cruzi transmission through the Triatomine vector takes place. All sera used in this study had serologically tested positive for Chagas disease. 
Kala-azar: Serum samples were obtained from 40 Kala-azar patients. Twenty eight samples were obtained from in-patients at several hospitals in the Federal District, Brasilia. The remaining cases came from the Infectious Disease Division at the Hospital of the University of Bahia. Brazil. In every case the diagnosis was made by direct demonstration of amastigotes of $L$. chagasi in bone marrow cells and/or by sub-culture in blood agar.

Mucocutaneous leishmaniasis: Serum samples were obtained from 63 patients from the Três Braços county, Bahia. Brazil, where the disease is endemic. In every case the skin biopsy showed the amastigote forms in the phagocytic cells at the border of ulcerated leishmaniasis lesions, or by inoculation of macerated tissue in susceptible hamsters. with subsequent recovery of the parasite from resulting lesions.

Controls: Fifty-six control sera were obtained from healthy street-sweepers at the Cleaning Department of Brasilia. Brazil. None of the individuals had lived in endemic areas for any of the diseases under consideration. The serum samples were stored at $-20^{\circ} \mathrm{C}$ until use.

\section{Immunologic assays:}

ELISA: The standard ELISA assay was carried out on 96-well plates (Dynatech, USA). The optimal concentration of antigen was determined by checkerboard titration experiments carried out according to standard procedure ${ }^{21}$. Thereafter, the quantity of $0.1 \mu \mathrm{g}$ of protein in each antigen diluted in carbonate buffer saline solution, $\mathrm{pH} 9.6$, was used to coat the negatively charged plate wells overnight, at $4^{\circ} \mathrm{C}$. The excess of antigen was discarded and the plates were washed three times with PBS/Tween 20 at $0.05 \%$ (v/v). The non-specific binding sites were blocked by a $2 \%$ suspension of non-fat milk in the same solution. The antigen-sensitized plates were washed three times with PBS-Tween, air dried at room temperature and stored at $-20^{\circ} \mathrm{C}$. Fifty $\mu 1$ of serum dilutions were placed on the wells and the plates were incubated for $1 \mathrm{~h}$ at room temperature. After automated washings, (Utrawash. Dynatech Laboratories) the wells received $50 \mu \mathrm{l}$ of a 1:1000 dilution of peroxidase-labelled rabbit anti-human IgG (Cappel Laboratories, USA), and the reaction that was formed after washing and incubating for 10 minutes with a mixture of ortho-phenylenediamine and hydrogen peroxide was stopped by addition of $1 \mathrm{~N} \mathrm{H}_{2} \mathrm{SO}_{4}$. The optical densities were read in a Titertekplus spectrophotometer at a wavelength setting of $490 \mathrm{~nm}$.

Indirect hemagglutination (IH): This procedure was performed according to a technique previously described ${ }^{17}$. A positive result was indicated by agglutinated red cells lining the bottom of the wells with serum dilutions above 1:8.
Indirect immunofluorescence (IF): This assay was run as described by CAMARGO ${ }^{2}$. The fluorescein-conjugated anti-human IgG (Cappel Laboratories, USA) was used in the dilution 1:100. A positive result was indicated by apple-green staining of the parasite silhouete with serum dilutions above $1: 20$.

Direct agglutination: Serial dilutions of each serum sample were carried out on the wells of microtitration plates. Fifty $\mu \mathrm{l}$ of the serum in saline solution containing $1 \%(\mathrm{v} / \mathrm{v})$ FCS and 0.1 M 2-mercaptoethanol were placed on the wells, which received equal volume of the formaldehyde-killed parasite suspension. The plate was covered with a plastic membrane and incubated for $24 \mathrm{~h}$ at room temperature in a moist chamber. Positive and negative control sera were used in these assays. Agglutination of the parasite forms by serum dilutions 1:512 and above was scored as positive ${ }^{8}$.

Western blot: SDS-PAGE analyses of the whole cell protein $(1 \mathrm{mg} / \mathrm{ml}$ of protein) were carried out in $10 \%$ gels. according to the procedure described by LAEMMLI ${ }^{9}$. The proteins in the gel were transferred to nitrocellulose membrane (Multiphor II, Pharmacia, Sweden), according to TOWBIN $^{20}$. The $3 \mathrm{~mm}$ width nitrocellulose strips were incubated with borate-buffered saline solution (BBS), $\mathrm{pH}$ 7.2 , containing $2 \%$ non-fat milk for $3 \mathrm{~h}$ at room temperature with gentle shaking. In these assays the L. chagasi antigen required $5 \%$ non-fat milk. After three washings in BBS-milk the strips were treated with a 1:1000 dilution of peroxidase-labelled rabbit anti-human IgG (Cappel Laboratories) and incubated for $2 \mathrm{~h}$ at room temperature. The strips were washed and then treated with 4-chloro-naphtol and hydrogen peroxide to reveal the protein bands. The $M_{w}$ of each band was calculated by using Sigma molecular weight standards: Carbonic anhydrase (29,000); Ovalbumin (45,000): Bovine albumin (66.000); Phospholipase-B (97,400); B-galactosidase (1 16,000); and Myosin (205,000).

\section{RESULTS}

The results of serologic assays carried out with sera of Chagas disease, Kala-azar and Mucocutaneous leishmaniasis patients are shown in Table 1. In these assays each serum was screened with homologous and heterologous antigens by ELISA, IH, and IF. All serum samples from chagasic patients yielded antibody titers above the control sera by each serologic test employing $T$. cruzi antigen. However, all Kala-azar and Mucocutaneous leishmaniasis samples also showed high IF antibody titers against the same $T$. cruzi antigen. In addition. $10 \%$ of the Kala-azar and $55 \%$ of the Mucocutaneous leishmaniasis sera yielded $\mathrm{IH}$ antibody titers, whereas $15 \%$ and $5 \%$, respectively, reacted in ELISA with the $T$. cruzi soluble antigen. None of the control sera yieided a positive serologic reaction when this antigen was used. 
TABLE 1

Cross-reactivity among sera from Chagas disease, Kala-azar and Mucocutaneous leishmaniasis patients*.

\begin{tabular}{cccccccccccc}
\hline & \multicolumn{1}{c}{} & \multicolumn{1}{c}{ A. cruzi } & \multicolumn{3}{c}{ Antigens } \\
Antisera & Total & ELISA & $\begin{array}{c}\text { HI } \\
(\%)\end{array}$ & IF & ELISA & HI & IF & ELISA & HI & IF \\
& & $(\%)$ & $(\%)$ & $(\%)$ & $(\%)$ & $(\%)$ & $(\%)$ & $(\%)$ \\
\hline Chagas & 64 & 100 & 100 & 100 & 98 & 14 & 35 & 100 & 3 & 70 \\
Kala-azar & 40 & 15 & 10 & 100 & 100 & 47 & 100 & 100 & 2 & 100 \\
MCL & 63 & 5 & 55 & 100 & 100 & 14 & 35 & 100 & 14 & 100 \\
Controls & 56 & 0 & 0 & 0 & 2 & 12 & 0 & 2 & 2 & 0 \\
\hline
\end{tabular}

* Sera from Chagas disease, Kala-azar and Mucocutaneous Leishmaniasis (MCL) patients were submitted to ELISA, IH and IF assays using homologous and heterologous antigens, whose cut-offs were $O D=0.1$, and 1:8 and 1:20 dilutions, respectively. See material and methods for details.

All Kala-azar patients sera yielded high antibody titers by ELISA and IF assays with the homologous antigen. However, the ELISA also showed high antibody titers in $98 \%$ of the Chagas sera and in $100 \%$ of the Mucocutaneous leishmaniasis sera tested with $L$. chagasi antigen. Also, the IF showed $35 \%$ positive results when both, the Chagas and the Mucocutaneous leishmaniasis sera were employed. The IH showed positive results in $47 \%$ of these sera tested with the homologous $L$. chagasi soluble antigen. In addition, the $\mathrm{IH}$ also showed $14 \%$ positive results when the Chagas and the Mucocutaneous leishmaniasis sera were tested with this antigen.

All Mucocutaneous leishmaniasis patients sera yielded high antibody titers by ELISA and IF assays with the homologous $L$. braziliensis antigen, whereas IH gave positive results with the same antigen in $14 \%$ of the cases. It was disturbing to observe that all the Chagas and Kala-azar sera yielded high antibody titers by ELISA against $L$. braziliensis soluble antigen. Similarly, the IF assay yielded cross-reacting antibody titers with $100 \%$ of the Kala-azar sera and with $70 \%$ of the Chagas sera, when this same antigen was used. Control sera also yielded a few positive serologic tests when the $L$. chagasi $(12 \%)$ and the $L$. braziliensis $(2 \%)$ antigens were used (Table 1).

The profiles of $\mathrm{IH}$ antibody titers in 64 Chagas patients sera assayed with $T$. cruzi, $L$. chagasi and $L$. braziliensis soluble antigens are shown in Figure 1. The homologous antigen revealed antibody titers above 1:64 in all cases. In $87 \%$ of the cases the titers ranged between $1: 256$ and $1: 4096$. In contrast, seven Kala-azar sera showed anti- $T$. cruzi antibody titers below 1:64, and two cases of Mucocutaneous leishmaniasis showed antibody titer 1:32. Figure 2 shows the profiles of the ELISA antibody titers in the Chagas sera. The absorbance obtained in the ELISA with the $T$. cruzi antigen peaked at 0.6 in $44 \%(28 / 64)$ of the cases. On the other hand, the absorbances recorded for both $L$. chagasi and $L$. braziliensis antigens peaked at 0.2 and 0.4 , respectively. The absorbances obtained in the control experiments were significantly lower $(<0.1$, data not shown).

Figure 3 shows the profiles of antibodies demonstrated by ELISA in the sera of Kala-azar patients assayed with L. chagasi. L. braziliensis and T. cruzi antigens. The absorbances obtained with the $L$. chagasi and $L$. braziliensis antigens were similarly high and usually much above those seen when the $T$. cruzi antigen was used. All those absorbances are significantly higher $(>0.2)$ than those observed when 56 control sera were used $(<0.1$, data not shown). Figure 4 shows results of the ELISA in 63 Mucocutaneous leishmaniasis patients sera against $L$. braziliensis, $L$. chagasi and $T$. cruzi antigens. All these sera reacted strongly with the former two antigens, whereas only two cases showed absorbances above 0.1 with the $T$. cruzi antigen.

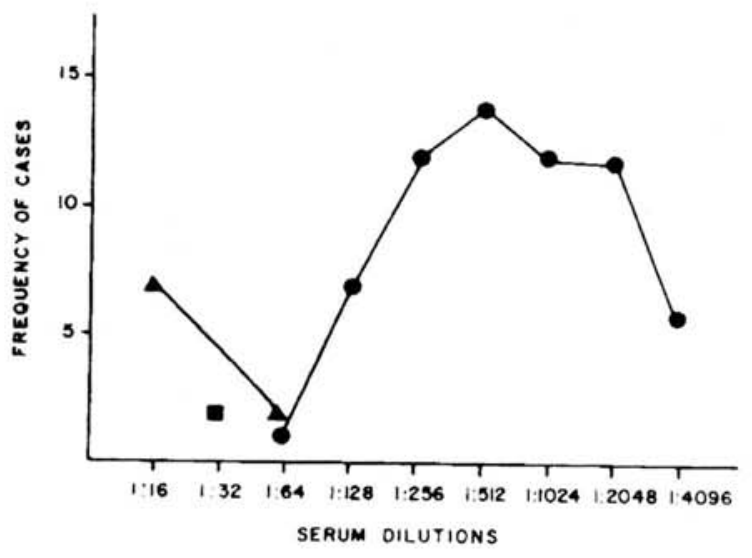

Fig. 1: Indirect hemagglutination antibody titers in 64 Chagas disease patients sera assayed with Trypanosoma cruzi $(\bullet \bullet \bullet)$. Leishmania chagasi $(\mathbf{\Lambda}-\mathbf{\Lambda})$ and Leishmania braziliensis $(\bullet)$ soluble antigens. High antibody titers above 1:64 was shown by the homologous antigen. Nine sera also showed antibodies (>1:16) against $L$. chagasi, and two cases showed antibodies against $L$. braziliensis. All 56 six control sera used in this study showed IH antibody titers $<1: 8$. 
An attempt was made to distinguish $L$. chagasi from $L$. braziliensis and from $T$. cruzi infections by means of the direct agglutination of formaldehyde-killed $L$. chagasi promastigotes in suspension. It was shown that $95 \%(19 / 20)$ of the Kala-azar and $35 \%(7 / 20)$ of the Mucocutaneous leishmaniasis sera tested presented parasite agglutination in dilutions above 1:512. In contrast, $15 \%(3 / 20)$ of the

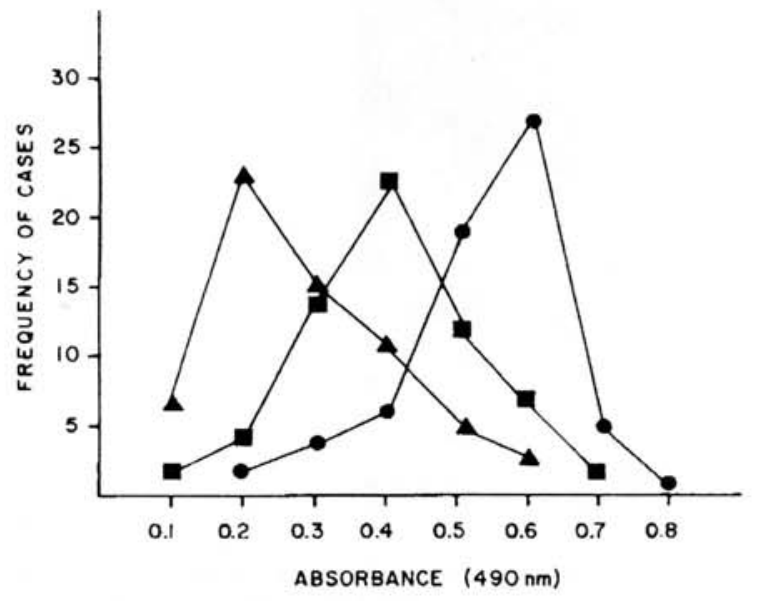

Fig. 2: Profiles of $\operatorname{lgG}$ antibodies shown by ELISA in 64 Chagas disease sera tested with Trypanosoma cruzi $(\bullet \bullet)$, Leishmania chagasi ( $\mathbf{\Lambda})$ and Leishamania braziliensis (-) soluble antigens. Notice close similarity of profiles, despite that the absorbances of the reactions of antibodies with the homologous antigens were usually stronger than those obtained with heterologous antigens. Also, cross-reactivity among these sera and L. brasiliensis antigen was usually stronger than that obtained with

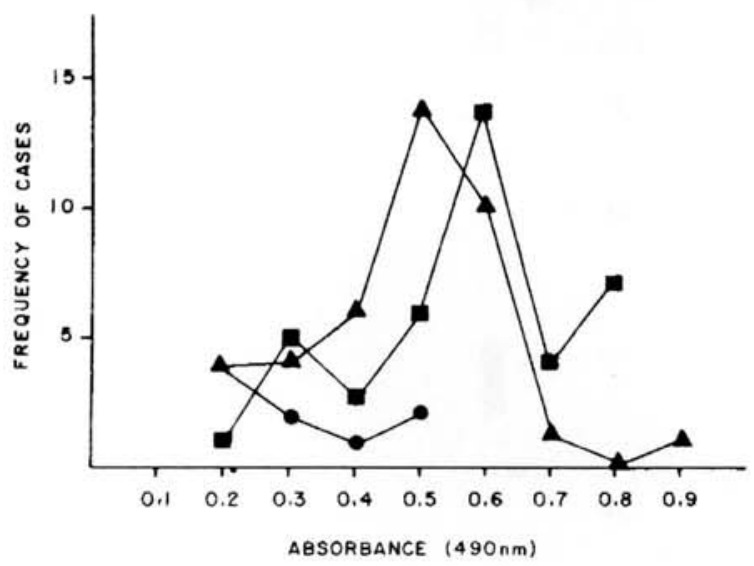

Fig. 3: Profiles of $\mathrm{lgG}$ antibodies shown by ELISA in $40 \mathrm{Kala}$-azar

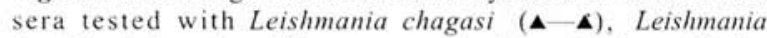
braziliensis (- -) and Trypanosoma cruzi $(\bullet \bullet)$ antigens. Notice similarity of profiles among optical densities obtained when these sera reacted with the Leishmania sp. soluble antigens. Eleven of these sera also showed cross-reactive antibodies against $T$. cruzi and yielded absorbances $>0.15$. All the 56 control sera yielded optical densities $<0.1$. chagasic sera used showed parasite agglutination in dilutions 1:16 and below (Figure 5).

The Western blot assay was used to study the pattern of proteins recognized by these sera. The Chagas patients sera revealed at least 24 antigenic bands, ranging from 245 to $7 \mathrm{kDA}$, in the $T$. cruzi soluble antigen. The Kala-azar sera

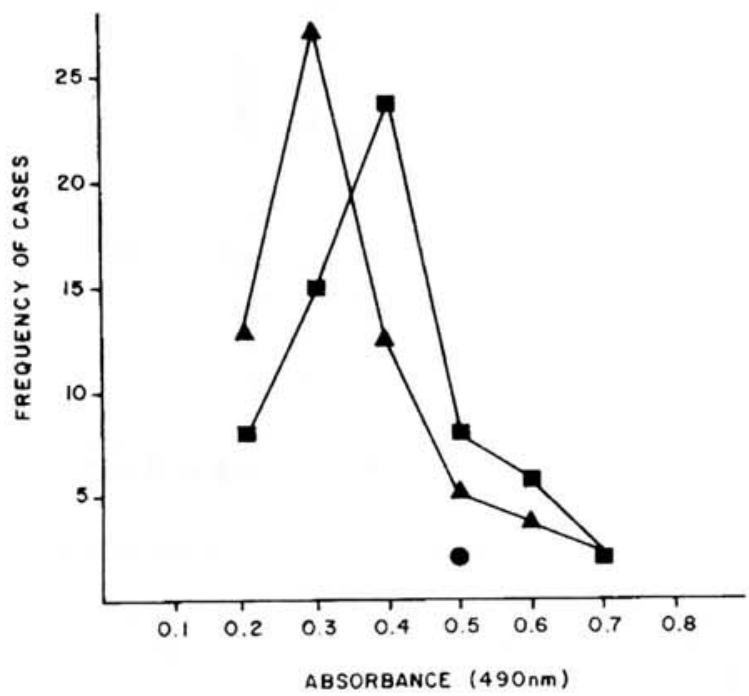

Fig. 4: Profiles of anti-IgG antibodies shown by the ELISA in 63 Mucocutaneous Leishmaniasis sera tested with Leishmania braziliensis (- - ) , Leishmania chagasi ( $-\mathbf{\Lambda})$, and Trypanosoma cruzi $(\bullet)$ soluble antigens. All these sera showed strong reactivity against the Leishamania sp. antigens, but only two showed cross-reactivity to $T$. cruzi. All 56 control sera showed negative results indicated by absorbances $<0.1$.

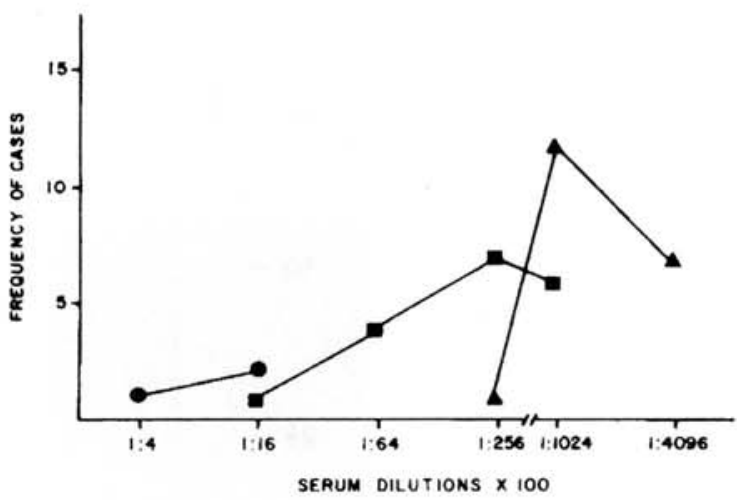

Fig. 5: Direct agglutination of formaldehyde-killed promastigotes of L. chagasi. Notice that $95 \%$ of the Kala-azar (- $)$ ) and $35 \%$ of the Mucocutaneous leishmaniasis (- - ) sera showed agglutination of the parasite forms in dilutions $>1: 512$. In contrast, all the Chagas $(\bullet \bullet)$ sera showed agglutination in dilutions 1:16 and below. 

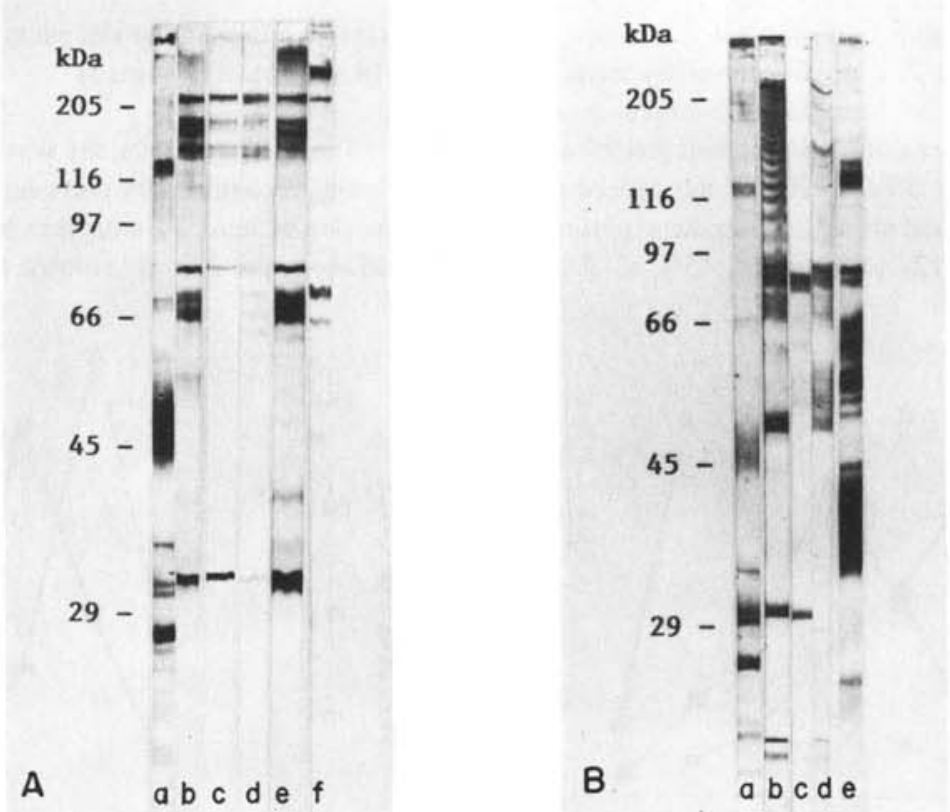

Fig. 6: Western blot analysis of Chagas sera showing cross-reactivity with Leishmania sp. soluble antigens. A) lane a, standard bands formed when the Chagas serum reacted with the Trypanosoma cruzi antigen; Lanes b to e, bands formed when Chagas sera cross-reacted with Leishmania braziliensis soluble antigen; Lane $\mathbf{f}$, shows bands formed when the Mucocutaneous leishmaniasis serum reacted with the homologous antigen. B) lane a, standard bands formed when the Chagas serum reacted with the homologous antigen; Lanes b to d, bands formed when these sera cross-reacted with Leishmania chagasi antigen. Lane e, bands formed when Kala-azar serum reacted with the homologous antigen.

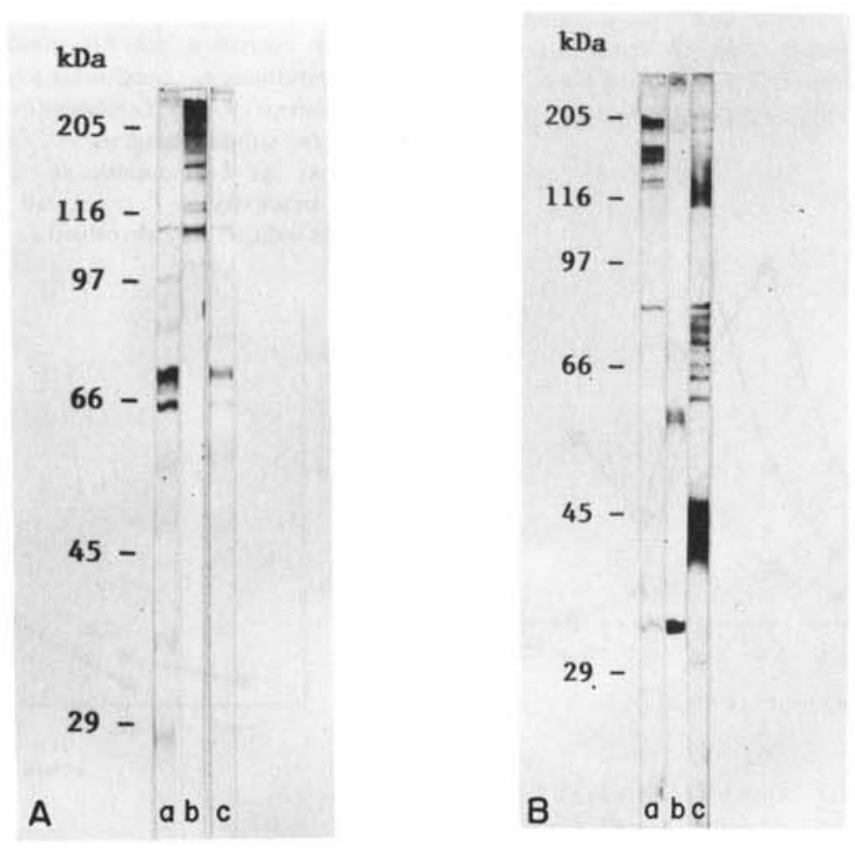

Fig. 7: Western blot analysis of Leishmania braziliensis sera showing cross-reactivity with Trypanosoma cruzi and Leishmania chagasi. A) Lane a, standard bands formed when Mucocutaneous leishmaniasis serum reacted with L. braziliensis antigen. Lanes b and c, bands formed when these sera cross-reacted with $T$. cruzi antigen. B) Lane a, standard bands formed when Mucocutaneous leishmaniasis serum reacted with the $L$. braziliensis antigen. Lane $\mathbf{b}$, bands formed when the serum cross-reacted with $L$. chagasi antigen. Lane $\mathbf{c}$, standard bands formed when the Kala-azar serum reacted with the L. chagasi antigen. 

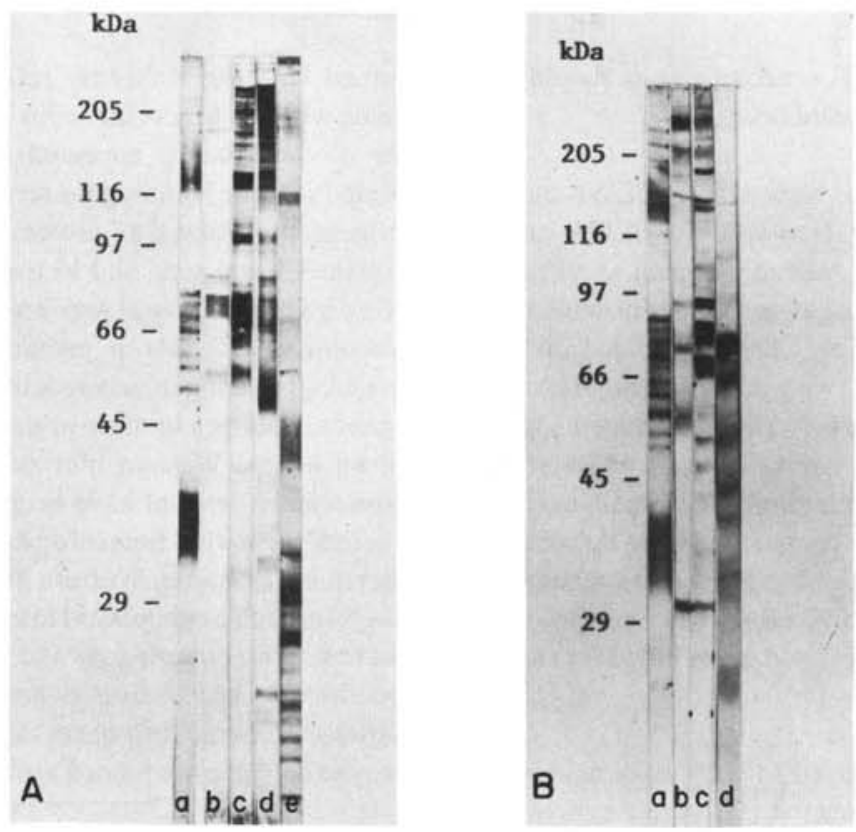

Fig. 8: Western blot analysis of Kala-azar sera showing cross-reactivity with Trypanosoma cruzi and Leishmania braziliensis soluble antigen. A) lane a, standard bands formed when Kala-azar serum reacted with the Leishmania chagasi antigen. Lanes b to d, bands formed when these sera cross-reacted with $T$. cruzi soluble antigen. Lane e, standard bands formed with Chagas sera and $T$. cruzi antigen. B) lane a, standard bands formed with the Kala-azar serum and the homologous antigen. Lanes b to c, bands formed with Kala-azar sera and $L$. braziliensis. Lane d, standard bands formed with Mucocutaneous leishmaniasis serum and the homologous antigen.

also revealed at least 14 bands cross-reacting antigens, whereas the Mucocutaneous leishmaniasis sera cross-reacted with 10 bands. Figure $6 \mathrm{~A}$ shows $\mathrm{M}_{\mathrm{r}} 250,245$, $210,129,123$ and $69 \mathrm{kDa}$ bands formed when the $T$. cruzi soluble antigen was treated with either the homologous sera or with the Mucocutaneous leishmaniasis sera. Figure $6 \mathrm{~B}$ shows $M_{r}$ 250, 220, 133, 129, 123, 76 and $74 \mathrm{kDa}$ bands when the same antigen was analysed with the anti-Kala-azar sera.

We also assayed by Western blot the L chagasi soluble antigen with homologous and heterologous sera. It was shown that at least 29 bands ranging in size from 250 to $8 \mathrm{kDa}$ formed with the Kala-azar sera. The same antigen formed 13 bands with the Chagas sera and at least 4 bands with the Mucocutaneous leishmaniasis sera. Of interest, the $250,220,133,129,123,76$ and $64 \mathrm{kDa}$ bands were present when both the Kala-azar and the Chagas sera were used. The $133 \mathrm{kDa}$ band was also present among the several bands formed when the Mucocutaneous Leishmaniasis sera was used (Figure 7).

Finally, the L. braziliensis soluble antigen was analysed with homologous and heterologous sera. At least 17 bands were observed when the proteins in the antigen reacted with
Mucocutaneous Leishmaniasis and Chagas sera, whereas the Kala-azar formed 15 bands. The 250, 245, 210, 150, 129. 123 and $69 \mathrm{kDa}$ bands shown by the homologous antisera were also identified by the Chagas sera. However, the Kala-azar sera showed only 250,245 and $210 \mathrm{kDa}$ bands in the same antigen. Figure 8 shows profiles of cross-reactivity of Kala-azar sera that showed positive serologic tests with $T$. cruzi and L. braziliensis antigens.

\section{DISCUSSION}

In this study, the assays employed in the diagnosis of Chagas disease yielded positive reactions in all the sera from $T$. cruzi infected individuals when the homologous antigen was used. Control sera did not yield positive reactions in these assays. In marked contrast, the specificity of these reactions showed broad variations according with the assay used. For instance, the IF assay showed positive reactions with all Kala-azar antisera, and, also, with $55 \%$ of the mucocutaneous leishmaniasis sera. The IH and ELISA also showed several positive reactions with Kala-azar and with the Mucocutaneous leishmaniasis sera, albeit to much lesser degrees, when the $T$. cruzi antigen was used. These observations are particularly important in those geographic regions where these diseases are sympatric. In this regard, future serologic studies to 
determine the prevalence of $T$. cruzi infections should take in consideration the data reported here.

The serologic diagnosis of Kala-azar by ELISA or IF is twice as sensitive than by $\mathrm{IH}$. However, the ELISA carried out with $L$. chagasi antigen yielded as much as $98 \%$ and $100 \%$ positive results with Chagas and with Mucocutaneous leishmaniasis sera, respectively. The IF yielded $35 \%$ of positive cross-reactivities with these sera. The low sensitivity of the IH assay with $L$. chagasi antigen appears to rule out its employment for serodiagnosis of Kala-azar. Since the features of Visceral leishmaniasis (Kala-azar) are quite typical and distinct from Mucocutaneous leishmaniasis, the questions arising from cross-reactivities can be resolved clinically. These cross-reactions, however, should be considered carefully in screening blood for various purposes.

It has been shown that the ELISA and IF assays are highly sensitive for accomplishing serodiagnosis of Mucocutaneous leishmaniasis. These assays, however, yielded $100 \%$ cross-reactions with Kala-azar sera. In addition, the ELISA showed $100 \%$ cross-reactions with Chagas sera, whereas the IF showed $70 \%$ of positive reactions with same sera. However, the direct agglutination of L. chagasi-killed promastigote assay separated $T$. cruzi from the other two kinetoplastid infections. Furthermore, this assay yielded $95 \%$ and $35 \%$ positive results (above 1:512) with Kala-azar and Mucocutaneous leishmaniasis sera, respectively. In fact, it becomes practically impossible to indicate the causal agent of clinically silent infections caused by $T$. cruzi, L. braziliensis or L. chagasi on a strictly serologic basis. Of course, the reported serologic cross-reactivities should be considered in epidemiologic inquires and in field-research studies in those regions where the diseases are endemic.

We analysed the serologic cross-reactivities by Western blot and showed several common antigenic determinants (epitopes) in the soluble antigens from each kinetoplastid protozoa employed in this study. With this respect, $14 \mathrm{~T}$. cruzi protein bands showed epitopes that can be recognized with Kala-azar sera, whereas the epitopes in 10 bands were recognized with Mucocutaneous leishmaniasis sera. There is a possibility that at least some of these epitopes are present in conserved proteins in those philogenetically related flagellates. In fact, six common protein bands in the $T$. cruzi soluble antigen were recognized by both Chagas and Mucocutaneous leishmaniasis sera. Also, seven common protein bands were recognized by the Kala-azar sera in the T. cruzi antigen.

The $L$. chagasi soluble antigen formed 13 bands with Chagas sera and six of these bands were common with those formed with the Kala-azar sera. This antigen formed for bands with the Mucocutaneous leishmaniasis sera, but only one of these bands appeared to be common with those formed with the homologous sera. The L. braziliensis soluble antigens also showed 17 protein bands that were recognized with the Chagas sera, and 15 bands with the Kala-azar sera. Of interest, the Chagas sera recognized common antigenic determinants in seven protein bands formed with the heterologous antigen, whereas the Kala-azar antigen showed common epitopes in three protein bands only. These bands shown by the Western blot assays should explain strong cross-reactivities that have been observed when these sera reacted with the heterologous antigen. Furthermore, discrepancies among Western blot profiles within groups of sera from each kinetoplastid infection, that were revealed by reactions with homologous and heterologous antigens (data not shown), may reflect a broad diversity of individual humoral immune responses towards these kinetoplastid parasite antigens associated with host interactions.

\section{RESUMO}

\section{Reatividade cruzada de anticorpos em pacientes com infecções pelos protozoários Trypanosoma cruzi, Leishmania chagasi e Leishmania (Viannia) braziliensis.}

Foram detectados anticorpos, nos soros de pacientes com doença de Chagas, Calazar e Leishmaniose cutâneo-mucosa, que se ligam a antígenos compartilhados pelos três agentes causais. Os pacientes chagásicos mostraram 98 a $100 \%$ de soropositividade pelo ELISA quando antígenos de Leishmania braziliensis e de Leishmania chagasi foram usados, respectivamente. Os soros de Calazar mostraram resultados positivos com antígenos de Trypanosoma cruzi ou com L. braziliensis pela imunofluorescência. Ademais, os anticorpos nos soros de pacientes com Leishmaniose cutâneo-mucosa tinham 100\% de resultados positivos pelo ELISA com antigenos de $T$. cruzi ou de L. chagasi. Ademais, a aglutinação direta de promastigotas de $L$. chagasi mostrou que $95 \%$ dos soros de Calazar e $35 \%$ de Leishmaniose cutâneo-mucosa algutinaram o parasito em diluições acima de 1:512. Em contraste, $15 \%$ dos soros chagásicos aglutinaram o parasito na diluição de 1:16 ou abaixo.

Análises pelo Western blot mostraram que os soros chagásicos que formaram pelo menos 24 bandas com antígeno de $T$. cruzi também foramaram 13 bandas com antígeno de L. chagasi e 17 bandas com L. braziliensis. Os soros de Calazar que reconheceram pelo menos 29 bandas com o antígeno homólogo também formaram 14 bandas com o $T$. cruzi e 10 bandas com L. braziliensis. Finalmente, os soros de Leishmaniose cutâneo-mucosa que formaram pelo menos 17 bandas com o antígeno homólogo também 
VEXENAT, A. de C.; SANTANA, J.M. \& TEIXEIRA, A.R.L. - Cross-reactivity of antibodies in human infections by the kinetoplastid protozoa Trypanosoma cruzi, Letshmania chagasi and Leishmania (Viannia) braziliensis. Rev. Inst. Med. trop. S. Paulo, 38(3):177-185, 1996.

formaram 10 bandas com os antígenos de $T$. cruzi e quatro com L. braziliensis. Esses resultados indicam a presença de determinantes antigênicos comuns em várias proteinas desses protozoários e, portanto, explicam as reações sorológicas cruzadas descritas aqui.

\section{REFERENCES}

1. ALENCAR, J.E.: ALMEIDA, Y.M.: SILVA, Z.F.: PAIVA, S.A. \& FONSECA, M.F. - Aspectos atuais do Calazar no Ceará. Rev. bras. Malar., 25:27-53, 1974.

2. CAMARGO, M.E. - Fluorescent antibody test for the serodiagnosis of American Trypanosomiasis: technical modification employing preserved culture forms of Trypanosoma cruzi in a slide test. Rev. Inst. Med. trop. S. Paulo, 8:227-234, 1966.

3. CAMARGO, M.E. \& REBONATO, C. - Cross-reactivity in immunofluorescence test for Trypanosoma and Leishmania antibodies. A simple inhibition procedure to ensure specific results. Amer J. trop. Med. Hyg., 18:500-505, 1969.

4. CHILlER, T.M.: SAMUDIO, M.A. \& ZOULEK, G. - IgG antibody reactivity with Trypanosoma cruzi and Leishmania antigens in sera of patients with Chagas' disease and leishmaniasis. Amer. J. trop. Med. Hyg., 43:249-259, 1990.

5. CUBA-CUBA, C.A.; MARSDEN, P.D.; BARRETO, A.C. et al. - Parasitologic and immunologic diagnosis of American (mucocutaneous) leishmaniasis. Bull. Pan Amer. Hith. Org., $15: 249-259,1981$

6. EVANS, D.A. - Leishmania reference strains. Parasit. today, 1:172-173, 1985.

7. GRIMALDI Jr., G.; TESHL, R.B. \& MCMAHON-PRATT, D. - A review of the geographic distribution and epidemiology of leishmaniasis in the New World. Amer. J. trop. Med. Hyg., 41:687-725, 1989

8. HARITH, A.E.; KOLK, A.H.J.; MINTER GOEDBLOED, E.; KAGER, P.A. \& KOLK, A.H.J. - Improvement of a direct agglutination test for field studies of visceral leishmaniasis. J. clin. Microbiol., 26:1321-1325, 1988.

9. LAEMMLI, U.K. - Cleavage of structural proteins during assembly of the head of bacteriophage. Nature, 227:680-685, 1970 .

10. LOWRY, O.H.: ROSEBROUGH, N.J.; FARR, A.L. \& RANDALL. R.J. - Protein measurement with Folin phenol reagent. J. biol. Chem., 193:265-275, 1951.

11. MALCHIODI, E.L.; CHIARAMONTE, M.G.; TARANTO, N.J.: ZWIRNER, N.W. \& MARGNI, R.A. - Cross-reactivity studies and differential diagnosis of human infections caused by Trypanosoma cruzi and Leishmania spp; use of immunobloting and ELISA with a purified antigen (Ag163Bb). Clin. exp. Immunol., 97:417-423, 1994.

12. MARSDEN, P.D. - Leishmaniasis. New Engl. J. Med., 300:350-352, 1974

13. MASUDA, A.; NASCIMENTO, S.F.; GUERRA, C.S.; PARANHOS, G.S. \& FERREIRA, A.W. - Analysis of the specificity of human antibodies to antigens of Leishmania braziliensis braziliensis. Rev. Inst. Med. trop. S. Paulo, 31:228-234, 1989.

14. MOTT, K.E.; LEHMAN Jr., J.S.; HOFF, R. et al, - The epidemiology and household distribution of seroreactivity to Trypanosoma cruzi in a rural community in northeast Brazil. Amer J. trop. Med. Hyg., 25:552-562. 1976.

15. NEVA, F.A. \& GAM, A. - A complement-fixing antigen from Trypanosoma cruzi grown in cell cultures. Amer. J. trop. Med. Hyg., 26:37-46, 1977.

16. SHAW, J.J. \& LAINSON, R, - Ecology and epidemiology: new world. In: PETERS, W. \& KILLICK-KENDRICK, R., ed. The leishmaniasis in biology and medicine. London, Academic Press, 1987. v. 1, p. 291-363.

17. TEIXEIRA, A.R.L. \& PEREIRA, L.M. - Discrepâncias entre resultados de três reações sorológicas empregadas para diagnóstico da Doença de Chagas. Rev. bras. Biol., 42:789-795, 1981.

18. TEIXEIRA, A.R.L.; JUNQUEIRA Jr., L.F.; SOLÓRZANO, E. \& ZAPPALA, M. - Doença de Chagas experimental em coelhos isogênicos III/J. I. Fisiopatologia das arritmias e da morte súbita do chagásico. Rev. Ass. méd. bras., 29:77-83, 1983.

19. TEIXEIRA, A.R.L. - The stercorarian Trypanosomes. In: SOULSBY, E.J.L., ed. Immune response in parasitic infections: immunology, immunopathology and immunoprophy. laxis. Boca Raton, CRC Press, 1987, v. 3, p. 25-118.

20. TOWBIN, H.; STAEHLIN, T. \& GORDON, J. - Electrophoretic transfer of proteins from polyacrylamide gels to nitrocellulose sheets: procedure and some applications. Proc. nat. Acad. Sci. (Wash.), 76:4350-4354, 1979.

21. VOLLER, A.; DRAPPER, C.; BIDWELL, D.E. \& BARTLETT, A. - Microplate enzyme-linked immunosorbent assay of Chagas' disease. Lancet, 1:426-428, 1975.

22. WHO - Control of Chagas' Disease. Report of a WHO Expert Committee. Wld. HIth. Org. techn. Rep. Ser., (811):95, 1991.

Recebido para publicação em 30/10/1995

Aceito para publicação em 07/05/1996 